the differences above noted ${ }^{1}$ are of specific value." I I may add that I have recently seen the specimens of Tudor limestone exhibited in the Peter Redpath Museum, and my estimate of their value coincides exactly with that of Sir J. W. Dawson in 1888. As Sir J. W. Dawson most kindly promises his assistance to other workers, perhaps he would submit to some of them any specimens from Tudor which he regards as more conclusive than his original type.

It would seem rather unnecessary for anyone to trouble to infer from my paper that Sir J. W. Dawson has "regarded the Madoc and Tudor specimens as "Lower Laurentian," when that is so directly stated by Sir J. W. Dawson in his description of his figure ; viz. "Specimen of Eozoon canadense embedded in a dark-coloured homogeneous limestone occurring in the Lower I aurentian series at Tudor, Canada West" (Quort. Foum. Geol. Soc., vol. xxiii. p. 265)

British Museum (Natural History), S.W.

\section{The Theory of Solutions.}

In his last letter (NAture, March 3, p. 4I5) Prof. Ostwald repeats his opinion that a theory is " a complex of laws, grouped around and derived from a main law," and infers from my letter that what I term a theory he would term an hypothesis.

If this were the whole point at issue, I could meet it in no better way perhaps than by referring Prof. Ostwald to his own works. For example, in his "Outlines of General Chemistry," are to be found not only numerous instances of the use of the word theory in its ordinary and accepted sense (e.g., p. 58) but also cases in which it is employed as synonymous with hypothesis (e.g., p. I87).

With regard to the definition of s lutions as mixtures, Prof. Ostwald maintains that even if hydrates are formed in a solution, the solution is finally a mixture of the hydrates and the remaining solvent. The real question involved is unaffected by this explanation. There is no doubt whatever that to the majority of readers the definition, without any qualifying clause, that solutions are mixtures leads to one conclusion and no othernamely, that between solvent and dissolved substance there is no interaction of a chemical nature. Prof. Ostwald has in his letters stated that in some cases he considers such interactions occur; he has also stated that between chemical and physical processes he knows of no distinction. The definition is at variance with both these views, and it seems but fair to conclude that sucb discordant statements tend in no way to obviate that misconception which Prof. Ostwald so often deplores.

In defence of the application of van der Waals's equation to solutions, a process questioned by me in my letter, Prof. Ostwald states that van der Waals himself has taken up this very question. The method by which van der Waals approaches the subject, curiously enough, furnished the main grounds for my objections. The most superficial comparison of the complex formula which van der Waals deduces for a mixture of two substances, with such an application of his simple gas equation to a solution as that given in Prof. Ostwald's book, is ample justification for my strictures. But apart even from such evidence as to the inadequacy of the application, the form which it is finally made to assume is in itself a proof of its incompleteness. By judicious simplification the application is made to take the shape of a linear equation in which "pressure forces due to the interacions of molecules are absent." That is to say, the cohesion of solvent and dissolved substance, and the mutual reactions of both, are alike ignored. Further comment on such a method of accounting for the phenomena of solutions appears to me to be superftious.

London, March 7 .

\section{The Limpet's Strength.}

The limpet experiments of your esteemed correspondent, Mr. Percy Aubin, as reported in NATURE of March 17 (p. 464) would have been still more interesting and instructive had he weighed the animals deprived of their shells.

On April IO, I890, I published my experiments showing that the sheli-less limpet pulls I984 times in the air its own weight, and about double when immersed in water.

r. i.e. between the specimen from Tudor and those from other localities. p. 43 .

"Specimens of Eozoon canadense," Mem. Peter Redpath Mus., I888, NO. II 69, VOL. 45]
Fasting fleas on an average pull 1493 times their own dead weight.

Other experimenters give the pulling power of the shelldeprived Venus verrucosa of the Mediterranean, a cockle-like creature, at 207I times the weight of its own body.

The force required to open an oyster appears to be 1319.5 times the weight of the shell-less oyster.

30 Sussex Square, Brighton, March ig.

$$
\text { J. Lawrence-Hamilton, M.R.C.S. }
$$

Technical Education for Novelists.

AMIDST the many schemes for technical education, could you not put in a plea for the "author of the popular novel"? Perhaps the need will best appear from these illustrations taken from the first 100 pages of a recently published and loudly heralded work.

(I) Scene-Kinder Scout, Derbyshire. Date-" after the snows and rains of early April," 1864. Time-after $8 p . \mathrm{m}$. "It was a clear, frosty night, promisiner a full moon."

(2) Same place, Easter Eve, 1864. "The wooded sides of the great moor were fading into dimness, and to the east a young moon was rising."

March 12.

\section{THE ORIGIN OF THE YEAR.}

I.

$\mathrm{T}$ would seem that in the dawn of civilization it was not at all a matter of course that the sun should be taken as the measurer of time, as it is now with us; and in this connection it is worth while to note how very various the treatment of this subject was among the early peoples. Thus, for instance, it was different in Egypt from what it was in Chaldæa and Babylonia, and later among the Jews. In the Egyptian inscriptions we find references to the moon, but they prove that she occupied quite a subordinate position to the sun; while in Chaldrea it would seem that the moon was the chief thing worshipped, and it was thus naturally the chief means used for measuring time, and, so far as months were concerned, this, of course, was quite right. In Chaldæa, too, where much desert travel had to be undertaken at night, the movement of the moon would be naturally watched with great care

An interesting point connected with this is that, among these ancient peoples, the celestial bodies which gave them the unit period of time by which they reckoned were practically looked upon in the same category. Thus, for instance, in Egypt the sun being used, the unit of time was a year; but in Chaldæa the unit of time was a month, for the reason that the standard of time was the moon. Hence, when periods of time were in question it was quite easy for one nation to conceive that the period of time used in another was a year when really it was a month, and vice versâ. It has been suggested that the years of Methuselah and other persons who are stated to have lived a considerable number of years were not solar years but lunar years - that is, properly, lunar months. This is reasonable, since if we divide the numbers by 12 we find that they come out very much the same length as lives are in the present day.

There seems little doubt that the country in which the sun was first definitely accepted as the most accurate measurer of time was Egypt.

"The Egyptians," says Ranke in the first chapter of his "Universal History," which is devoted to Egypt, "have determined the motion of the sun as seen on earth, and according to this the year was divided, in comparison with Babylon in a scientific and practically useful way, so that Julius Casar adopted the calendar from the Egyptians and introduced it into the Roman Empire; the other nations followed suit, and since then it has been in general use for seventeen centuries. The calendar may be considered the noblest relic of the most ancient times which has influenced the world." 